\title{
DEDICATION OF LAND IN CALIFORNIA
}

When a new subdivision is constructed, the owner normally desires to shift the responsibility for maintaining the streets to the local governing body. Similarly, a land developer often wishes to set aside park or beach lands for public use in order to increase the value of his development. These objectives can be obtained by dedicating the lands to the public. Unhke public acquisition of private lands by eminent domain or purchase, the governing body does not compensate the owner for lands acquired by dedication. Rather, the owner donates the lands to public use, and, if the donation is accepted, ownership is thereby transferred to the governing body. As land development by subdivision becomes more prevalent in Cahiforma, and as urban expansion continues at a rapid pace, it is increasingly important that the landowner, the lawyer, and the public official be aware of the legal status of lands dedicated to the public. Despite the importance of doctrinal stability and clarity in this area of the law, confusion and uncertainty prevail.

There are two types of dedication: (1) common law dedication, and (2) statutory dedication. Common law dedication involves the donation of land to public use under judicially created doctrines rather than under statutory regulations-it miglit more aptly be labeled non-statutory dedication. Since common law dedication is a voluntary transfer of an interest in land, it is governed by the fundamental principles which control gifts as well as those which govern grants. ${ }^{1}$ In California, common law principles of dedication have been modified because the state legislature has been dissatisfied with the results of common law dedication, and has attempted to control these results by enacting statutes. Many of these legislative enactments have created confusion and uncertainty in the law; others have produced undesirable or inequitable results. Moreover, these statutes are scattered throughout various codes and, consequently, are difficult to locate. Part I of this Comment examines some of the problems resulting from this legislative interference with the common law doctrines of dedication.

Statutory dedication, as the name suggests, involves the donation of land to public use in conformity with the provisions of a comprehensive set of integrated statutes. ${ }^{2}$ The owner must formally offer the land to the governing body, usually by submitting for approval and recording a subdivision map, and the public officials can accept the lands dedicated

${ }^{1}$ See, e.g., County of Inyo v. Given, 183 Cal. 415, 191 Pac. 688 (1920).

2 It is necessary that the parties substantially comply with the provisions of the statutes. Compare People v. Rio Nido Co., 29 Cal. App. 2d 486, 492, 85 P.2d 461, 465 (1938), with Galeb v. Cupertino Sanitary Dist., 227 A.C.A. 315, 323-24, 38 Cal. Rptr. 5so, 586 (1964). 
on the map only by formal resolution. ${ }^{3}$ Statutory regulation of land dedication in California is confined solely to subdivision development, governed by the Subdivision Map Act. ${ }^{4}$ Part II of the Comment discusses the current status of statutory dedication in California.

COMMON LAW DEDICATION

\section{A. Dedication Procedure}

Under the doctrine of common law dedication no particular formality is necessary to dedicate lands so long as there is an offer of dedication by the owner and an acceptance of the offer by the public or its representatives. ${ }^{5}$ The owner may indicate his intent to offer lands for public use by making an express grant of the land to the governing body, ${ }^{6}$ by referring to the dedication in a deed of land to a third person, ${ }^{7}$ by recording a map which includes a reference to lands donated to the public, ${ }^{8}$ by selling lots with reference to a map showing lands set aside for public use, ${ }^{0}$ or by acquiescing in public use of the lands. ${ }^{10}$ There need not be a specific grantee-land can be dedicated to and accepted by the members of the public as a whole.11 Acceptance of the owner's offer may be by formal municipal or county resolution, ${ }^{12}$ by acts of ownership by the governing body,$^{13}$ or by public use of the land. ${ }^{14}$ The owner can revoke his offer

3 See, e.g., Tischauser v. City of Newport Beach, 225 A.C.A. 181, 37 Cal. Rptr. 141 (1964); Gross v. City of San Diego, 125 Cal. App. 238, 13 P.2d 820 (1932).

4 Car. Bus. \& Prof. Code \$\$ 11500-641.

5 Compare City of Manhattan Beach v. Courtelyou, 10 Cal. 2d 653, 76 P.2d 483 (1938), with County of Inyo v. Given, 183 Cal. 415, 191 Pac. 688 (1920).

6 E.g., City of Los Angeles v. Pacific Elec. Ry., 168 Cal. App. 2d 224, 335 P.2d 1042 (1959).

7 E.g., City of Eureka v. Gates, 137 Cal. 89, 69 Pac. 850 (1902); Smith v. Kraintz, 201 Cal. App. 2d 696, 20 Cal. Rptr. 471 (1962); Wheeler v. City of Oakland, 35 Cal. App. 671, 170 Pac. 864 (1917). But see Flavio v. McKenzie, 218 Cal. App. 2d 549, 32 Cal. Rptr. 535 (1963), in which a reference in a deed to a "public highway" was leld not to be conclusive on the issue of the owner's intent.

8 E.g., Hayward v. Manzer, 70 Cal. 476, 13 Pac. 141 (1886) (offer by recording map but no acceptance by public); Fitzgerald v. Smith, 94 Cal. App. 480, 271 Pac. 507 (1928).

9 E.g., Berton v. All Persons, 176 Cal. 610, 170 Pac. 151 (1917).

10 E.g., Schwerdtle v. County of Placer, 108 Cal. 589, 41 Pac. 448 (1895); Arnold v. City of San Diego, 120 Cal. App. 2d 353, 261 P.2d 33 (1953).

11 City of Cincinnati v. White, 31 U.S. (6 Pet.) 431 (1832); Lake v. Tebbits, 56 Cal. $481(1880)$.

12 E.g., Stump v. Cornell Constr. Co., 29 Cal. 2d 448, 175 P.2d 510 (1946); City of Eureka v. Armstrong, 83 Cal. 623, 22 Pac. 928 (1890).

${ }^{13}$ E.g., Union Transp. Co. v. Sacramento County, 42 Cal. 2d 235, 267 P.2d 10 (1954); Smith v. Kraintz, 201 Cal. App. 2d 696, 20 Cal. Rptr. 471 (1962).

14 E.g., McKinney v. Ruderman, 203 Cal. App. 2d 109, 21 Cal. Rptr. 263 (1962). 
before it is accepted,$^{15}$ and acceptance of the offer must be made within a reasonable time. It is a question of fact whether a delay in acceptance will be deemed a rejection of the offer. ${ }^{16}$ Once the offer has been accepted, however, there is no possibility of revoking the dedication; ${ }^{17}$ the public cannot lose dedicated lands by non-use or by delay in use of the lands for the purpose for which they were dedicated, ${ }^{18}$ nor can lands dedicated by a private owner to a public use be lost by adverse possession. ${ }^{19}$ The procedures for pubhic abandonment of lands acquired by dedication are prescribed by statute. ${ }^{20}$ It appears, however, that under extenuating circumstances California courts will return dedicated lands to a private owner when there is a showing of conduct by the governing body such as affirmative acts of rejection or denial of ownership of the land resulting in irreparable injury to an innocent party acting in reliance on this conduct. $^{21}$

15 Eltinge v. Santos, 171 Cal. 278, 152 Pac. 915 (1915); City of Eureka v. Croghan, 81 Cal. 524, 22 Pac. 693 (1889).

${ }^{16}$ Compare Yuba City v. Consolidated Mausoleum Syndicate, 207 Cal. 587, 279 Pac. 427 (1929) (31 years not unreasonable), with People v. Reed, 81 Cal. 70, 22 Pac. 474 (1889) (over 20 years unreasonable). See text accompanying notes 133-35 infra.

17 City of Sacramento v. Jensen, 146 Cal. App. 2d 114, 303 P.2d 549 (1956).

18 People v. Myring, 144 Cal. 351, 354, 77 Pac. 975, 976 (1904); Archer v. Salinas City, 93 Cal. 43, 28 Pac. 839 (1892); Humboldt County v. Van Duzer, 48 Cal. App. 640, 644, 192 Pac. 192, 194 (1920).

19 The justification for this is that lands donated for the use of the public as a whole should not be lost by the negligence of public officials. See City of Visalia v. Jacob, 65 Cal. 434, 4 Pac. 433 (1884); Humboldt County v. Van Duzer, 48 Cal. App. 640, 192 Pac. 192 (1920); Wheeler v. City of Oakland, 35 Cal. App. 671, 675, 170 Pac. 864, 866 (1917); see CAL. Crv. CoDE $\$ 1007$. It has been lield that lands not acquired by dedication and not set aside for public use, but lield by a governing body in a proprietary capacity, may be lost hy adverse possession. Henry Cowell Lime \& Cement Co. v. California, 18 Cal. 2d 169, 114 P.2d 331 (1941); An1es v. City of San Diego, 101 Cal. 390, 35 Pac. 1005 (1894); Richert v. City of San Diego, 109 Cal. App. 548, 293 Pac. 673 (1931). See also Richards v. County of Colusa, 195 Cal. App. 2d 803, 16 Cal. Rptr. 232 (1961).

When a tax is assessed and paid on a tract of land as though it were privately owned, the public rights in any portion of the land are not lost. Smith v. City of San Luis Obispo, $95 \mathrm{Cal} .463,468,30 \mathrm{Pac}$. 591,592 (1892). The reasoning of this case would seem to compel the same result even if the tax were assessed solely on the dedicated parcel.

20 See County of San Diego v. California Water \& Tel. Co., 30 Cal. 2d 817, 823, 186 P.2d 124, 128 (1947); CAL. StrTs. \& Highs. CoDE $\S \S 954-60.5,8300-24$. It has been held that roads not acquired by deed or dedication may be informally abandoned by relocation of the road and non-use of its fonner site. Smith v. Ricker, 226 A.C.A. 146, 37 Cal. Rptr. 769 (1964); see also Humboldt County v. Van Duzer, 48 Cal. App. 640, 644, 192 Pac. 192, 194 (1920).

21 Compare City of Imperial Beach v. Algert, 200 Cal. App. 2d 48, 19 Cal. Rptr. 144 (1962), with County of Sacramento v. Lauszus, 70 Cal. App. 2d 639, 653, 161 P.2d 460, 468 (1945); Humboldt County v. Van Duzer, 48 Cal. App. 640, 646, 192 Pac. 192, 195 (1920); Wheeler v. City of Oakland, 35 Cal. App. 671, 675-76, 170 Pac. 864, 866 (1917).

In Imperial Beach, supra, a private owner was allowed to reclaim dedicated lands 


\section{B. Adverse Public User}

Under the doctrine of adverse user, no manifested intent by the owner to dedicate the land need be found. ${ }^{22}$ Rather, there arises a conclusive presumption of dedication when there is long, continuous, hostile, and adverse use by members of the public without the express permission of the owner. ${ }^{23}$

In 1954, the California Supreme Court indicated that a governing body should not be responsible for the maintenance of roads dedicated under the doctrine of adverse public user, but held that conconitant acts of ownership by a public official were sufficient to impose hability on the governing body for failure to maintain such roads. In Union Transportation Co. v. Sacramento County ${ }^{24}$ a bridge collapsed under a truck owned by the plaintiff. The trucking company alleged that the county had a duty to maintain the road and bridge because it had become a public highway by implied dedication arising froin long acquiescence by the adjacent landowners in its use by the public. The county argued that section 904 of the California Streets and Higlrways Code, which then

on the theory of equitable estoppel. The land in question was dedicated in 1948 under the provisions of the Subdivision Map Act. The parcel was never opened for street purposes and the municipality never made improvements or expenditures on the land. The board of supervisors formally closed the street to traffic and sought to quiet title against the defendant. In denying the city's quiet title action on the grounds of estoppel, the court was careful to limit its decision to the particular facts of the case.

The land in Imperial Beach had been dedicated in accordance with statutory provisions. If the land had been dedicated under common law principles, equitable estoppel could be asserted against a mumcipality with a showing of fewer special circumstances. See County of San Diego v. Cahiforma Water \& Tel. Co., 30 Cal. 2d 817, 825, 186 P.2d 124, 130 (1947).

22 It is important to distinguish true adverse user from cases in which an actual and mamifest offer of dedication by the owner is accepted by public use of the land. When an owner offers land for dedication, the public may accept the dedication by using the lands for a relatively short period of time. See Schwerdtle v. County of Placer, 108 Cal. 589, 41 Pac. 448 (1895).

23 See Hartley v. Vermillion, 141 Cal. 339, 74 Pac. 987 (1903); Arnold v. City of San Diego, 120 Cal. App. 2d 353, 261 P.2d 33 (1953). Civil Code $\S 813$ provides for recordation of a notice by a landowner that public use of his land is permissive only. The recorded notice is evidence that subsequent use of the land for the purpose described in the notice is permissive.

A prescriptive right to a private easement over the property of another person may be acquired by clear adverse use, openly, notoriously, and continuously asserted for the statutory period of five years. Dooling v. Dabel, 82 Cal. App. 2d 417, 186 P.2d 183 (1947). In comparing the doctrine of public user with that governing the acquisition of private easements by prescription, Califorma courts have insisted that public rights can arise only through dedication, which requires an actual or implied offer by the owner and an acceptance by the public. See, e.g., People v. Sayig, 101 Cal. App. 2d 890, 226 P.2d 702 (1951). When adverse use for the prescriptive period has been established, however, the orver's offer is conclusively presumed. Thus, in reality the only difference between the two doctrines is the mode of acceptance-public or private use.

2442 Cal. 2d 235, 267 P.2d 10 (1954). 
provided that "no route of travel used by one or more persons over another's land shall become a county highway by use," prohibited dedication of the road and bridge to the public by adverse use. ${ }^{25}$ This defense was unsuccessful, however, for the court followed prior decisions which had abrogated the effect of the statute on the dubious theory that while mere use of the way for five years did not of itself constitute dedication, such use by the pubhic might be some evidence which, when taken with other evidence, could amount to sufficient proof of dedication. ${ }^{26}$ In this case there was "other evidence" that some time before the accident the county superintendent of roads had dispatched equipment to the section of the road in question with instructions to make repairs, and even though no repairs were actually made, the court held that the county had impliedly accepted the dedication and, thus, was liable for failure to maintain the road and bridge. ${ }^{27}$

An important question not squarely faced by the court in Union Transportation is what acts of ownership by a public official should be sufficient to justify a finding that the goverming body is liable for failure to maintain lands not formally accepted. In rejecting adverse user by itself as a basis for county hability, the court declared that public policy compels the conclusion that use by a small segment of the public alone should not charge the general public with the burden of maintenance. ${ }^{28}$ Similar reasoming would compel the conclusion that acts of a public off-

20 As the court points out, $\S 904$ is based on former Political Code $\S 2621$, Cal. Stats. 1883 , ch. $10, \S 1$, at 6 , which was enacted to end the confusion resulting from statutes applicable to particular counties which declared that roads used by the public for five years were public highways. Section 2621 was similar to $\$ 904$ except that the words "county highway" in § 904 were "public road or byway" in § 2621, and § 2621 included the words "or until so declared by the board of supervisors or by dedication by the owner of the land affected."

20 See, e.g., Lantz v. City of Los Angeles, 185 Cal. 262, 196 Pac. 481 (1921), in which continuous use for 14 years without objection from the owner justified a finding of implied dedication. The statute has been used as a nakeweight in cases where the facts fail to show sufficient public use. See, e.g., Bartholomew v. Stalieli, 86 Cal. App. 2d 844, 195 P.2d 824 (1948); Dunn v. County of Santa Cruz, 67 Cal. App. 2d 400, 154 P.2d 440 (1944).

27 Authority to make the repairs was given the county by Streets and Highways Code § 941. A political subdivision cannot be lield liable for failure to maintain public lands unless it has authority to perform such maintenance. Gillespie v. City of Los Angeles, $36 \mathrm{Cal}$. 2d 553, 225 P.2d 522 (1950).

28 The court discusses the two conflicting theories which have been used in other jurisdictions to justify a decision on the same problem. One theory, treating public officials as agents of the pubbic, imposes liability because of the inconsistency in allowing public user to establish a right against the landowner and nonetheless preventing the public from claiming a right against the government. The other theory demes liability on the ground that it would be unreasonable to allow a small segment of the public to impose a burden of maintenance on the public as a whole. The court felt that public policy compels the latter result. 
cial should constitute acceptance of maintenance responsibility for a road only if there was actual, periodic repair or improvement. ${ }^{20}$

In response to the holding in Union Transportation, the state legislature amended Section 941 of the California Streets and Highways Code to provide that:

No public or private road shall become a county highway until and unless the board of supervisors, by appropriate resolution, has caused said road to be accepted into the county road system; nor shall any county be held liable for failure to maintain any road unless and until it has been accepted into the county road system by resolution of the board of supervisors. ${ }^{30}$

A district court of appeal recently stated in Brick $v$. Keim ${ }^{31}$ that this statute does not mean that a road cannot be dedicated to the public by adverse user; it means merely that sucl a road does not become a county road and that the county, therefore, is not liable for failure to maintain such a public way. Since section 941 clearly protects the county from liability even though the land may become a public way by adverse user, and since the private owners of the abutting land will disclaim liability on the ground that the road has become a public way by adverse user, a person injured on sucl a public way which lias not been maintained will have no redress-a situation justifiable only if the injured person considered himself a trespasser or had no reason to believe that anyone might be responsible for maintenance of the way. Should the county road supervisor periodically send out a repair crew, the user miglt travel the way in reliance on continued city or county maintenance. Even in the case of such justifiable reliance, however, it is unlikely that an injured party could successfully invoke the doctrine of equitable estoppel against the county for it is only in exceptional cases that this doctrine can be used against a governmental body. This is especially true in a case where, as here, the legislature has declared a policy against such hability. ${ }^{32}$ Thus, it appears that the county board of supervisors

20 Cases have held that it is absurd to allow a taxing officer, by assessment of taxes, to determine whether land has been dedicated to the public. See, e.g., Smith v. City of San Luis Obispo, 95 Cal. 463, 468, 30 Pac. 591, 592 (1892); cf. Burk v. City of Santa Cruz, 163 Cal. 807, 811, 127 Pac. 154, 156 (1912).

30 The same protection is afforded cities under Streets \& Highways Code $\S 1806$.

31208 Cal. App. 2d 499, 25 Cal. Rptr. 321 (1962). In making this interpretation, the court held that $\S 941$ does not prevent the dedication of a public road. Since there was no question of county liability involved, the court was able to state only as dictum that by virtue of $\S 941$ the county could not be leld liable for failure to maintain the road. The court supported this dictum by pointing out the change in wording from "public road or byway" to "county highway" when former Political Code $\$ 2621$, Cal. Stats. 1883, ch. $10, \S 1$, at 6 , was amended to Streets \& Highways Code \& 904. See note 25 supra. Thus a public road but not a county highway may be created by adverse user.

32 County of San Diego v. California Water \& Tel. Co., 30 Cal. 2d 817, 186 P.2d 124 
can put off formal acceptance of the way indefinitely and thereby avoid liability for failure to nuaintain a county highway. Developnient of case law under the Union Transportation lolding would have produced a more equitable result. ${ }^{33}$ Injuries on roads dedicated but not formally accepted are too few to burden the municipality financially, and public reliance on the safety of these roads is too great to justify a bestowal of immunity on the governing body for failure to maintain these roads. ${ }^{34} \mathrm{~A}$ solution would be legislation providing that substantial repair or improvements coinpleted by the governing body on a public way will render the governing body responsible for future maintenance.

\section{Interest Acquired by the Public}

Once dedication is complete, it often becomes necessary to determine what interest in the land is acquired by the public and, conversely, what

(1947); but see City of Imperial Beach v. Algert, 200 Cal. App. 2d 48, 19 Cal. Rptr. 144 (1962), in which estoppel against the city was found despite the legislative policy prescribed under the Subdivision Map Act (Cax. Bus. \& Prof. Code $\$ \S 11500-641$ ). The Act is not mentioned.

${ }^{33}$ In Pennsylvania, for example, the courts have refused to leave a person who is injured on a public way without a remedy. In the absence of formal acceptance by the municipality, hability for failure to maintain a public way can be established by showing either long continued public user, see, e.g., Ackerman v. City of Williamsport, $227 \mathrm{~Pa}$. 591, 76 Atl. 421 (1910); Gass v. City of Pittsburgh, $91 \mathrm{~Pa}$. Super. 290 (1927), or authorized mumicipal acts from which acceptance may be implied, see, e.g., Wensel v. North Versailles TP, $136 \mathrm{~Pa}$. Super. 485, 7 A.2d 590 (1939). In Georgia, dedication by public use alone will not charge the municipality with liability for failure to repair, but when public officials cause the way to be repaired from time to time, the municipality is deemed to have accepted the way and it thus becomes responsible for its maintenance. See, e.g., Maddox v. Willis, 205 Ga. 596, 54 S.E.2d 632 (1949).

34 It is likely, however, that a city or county will still be liable for affirmative acts negligently performed on roads made public by adverse user but not formally accepted as a county or city road. See Van Alstyne, Governmental Tort Liability: Judicial Lawmaking in a Statutory Milieu, 15 Star. L. REv. 163, 208-09 (1963), in which the author points out a possible ambiguity in the phrase, "failure to maintain," as it appears in Streets \& Highways Code $\S 914$. Several California cases are cited in which the pohtical subdivision has been held hable not for a "failure to maimtain," but for the neghigent creation of a defective condition or the failure to provide for a foreseeable danger. See, e.g., Duran v. Gibson, 180 Cal. App. 2d 753, 4 Cal. Rptr. 803 (1960) (street made slippery by city water truck); Reel v. City of South Gate, 171 Cal. App. 2d 49, 340 P.2d 276 (1959) (unlighted obstacle left on road); Teilhet v. County of Santa Clara, 149 Cal. App. 2d 305, 308 P.2d 356 (1957) (dangerous road condition created by burning weeds); Wood v. County of Santa Cruz, 133 Cal. App. 2d 713, 284 P.2d 923 (1955) (tree trimmings left on road by county crew). The word "maintenance" as defined by Streets \& Highways Code $\$ 27$ has, since a 1959 amendment, been restricted to the keeping of roadways and related structures in a usable condition, providing necessary safety convemences and devices, and making emergency repairs.

It should be noted, also, that $\S 941$ does not apply to public parks, beaches, and other open spaces. The elements necessary to create a cause of action against a governing body for injuries occurring on public property are prescribed by Government Code $\$ 835$. 
interest is retained by the dedicator or his successors in interest. The question arises, for example, when minerals are discovered on the land and the dedicator demands all or a portion of the royalties, when the dedicated lands are taken by eminent domain and the dedicator demands a share of the proceeds, or when proceedings are brought by the dedicator to enjoin public officials from misusing dedicated lands.

In California the interest acquired by the public does not follow from the form or method of dedication-the courts have not distinguished between dedication by deed and other types of dedication, but lave looked to the purpose for which the lands were dedicated. If land is dedicated for street or highway use, the public merely acquires an easement across the land; ${ }^{35}$ if a parcel is dedicated for use as a park or beach, the public acquires a fee simple interest. ${ }^{36}$ The interest the grantor may have intended to donate to the public for the most part has been ignored ${ }^{37}$ It has been held that since the governing body held a fee title in dedicated park land, it could lease the land for mineral exploitation so

35 See, e.g., City of Los Angeles v. Pacific Elec. Ry., 168 Cal. App. 2d 224, 335 P.2d 1042 (1959).

36 See, e.g., Morse v. E. A. Robey Co., 214 Cal. App. 2d 464, 29 Cal. Rptr. 734 (1963). The first California case to state clearly that dedication of park lands to public use results in an acquisition by the governing body of a fee simple interest in the property held that deed conveyance of land for a public purpose will ordinarily vest the public with the same rights as if the land had been acquired by condemnation. Waslington Blvd. Beach Co. v. City of Los Angeles, 38 Cal. App. 2d 135, 100 P.2d 828 (1940). Two earlier park dedication cases, Slavich v. Hamilton, 201 Cal. 299, 275 Pac. 60 (1927), and Archer v. Salinas City, 93 Cal. 43, 28 Pac. 839 (1892), while failing to describe the legal title acquired by the public, did state that when dedication is complete the property becomes public property and the owner loses all control over it.

Generally under Code of Civil Procedure $\S 1239$, the estates subject to be taken by eminent domain are a fee simple to buildings, grounds, and reservoirs; an easement to roads; a right of entry to exploit resources; and a fee simple in any case if, by resolution, the governing body determines it is necessary. See also CaL. Gov't CoDE § 6953.

37 In many jurisdictions, the public acquires only an easement or right of way to the dedicated lands and the underlying fee is retained by the owner. See, e.g., Banks v. Ogden, 69 U.S. (2 Wall.) 57, 69 (1864); Barclay v. Howell, 31 U.S. (6 Pet.) 498, 513 (1832); Porter v. International Bridge Co., 200 N.Y. 234, 245-46, 93 N.E. 716, 718-19 (1910). Thus the public acquires only the incidents necessary to the enjoyment and maintenance of the right of way, which incidents cannot be exercised so as to injure the servient tenements. This result is attained in California when the public acquires an easement in lands dedicated for use as streets. See, e.g., Gurnsey v. Northern Cal. Power Co., 160 Cal. 699, 117 Pac. 906 (1911); Wright v. Austin, 143 Cal. 236, 76 Pac. 1023 (1904). The owner of the underlying fee, on the other hand, can use the land in any way not inconsistent with the public easement. See, e.g., Barclay v. Howell, 31 U.S. (6 Pet.) 498, 513; Smith v. Lemon, 166 Ga. 93, 97-98, 142 S.E. 554, 556 (1928); Lade v. Shepherd, 2 Strange 1004 (1735). This does not mean, however, that the public can never obtain a fee interest in dedicated lands. In fact, it is generally held that if the donor so intends, a dedication by deed will transfer a fee interest to the public. See, e.g., United States v. 5.324 Acres of Land, 79 F. Supp. 748, 753 (S.D. Cal. 1948); Central Land Co. v. City of Grand Rapids, 302 Mich. 105, 108, 4 N.W.2d 485, 486 (1942); Green v. Kunkel, 183 S.W.2d 585 (Tex. Ct. Civ. App. 1944). 
long as the slant drilling from adjoiming land did not interfere with the surface enjoyment of the park, ${ }^{38}$ the court ignoring the possibility that removal of subsurface support could destroy the surface potential of the land..$^{39}$ Although recognition of a fee interest in the city may allow it to make such undesirable use of dedicated lands, by acquiring a fee interest in park lands a governing body may better protect these lands from misuse by a person claiming a retained interest in the land. ${ }^{40}$

It is understandable that, with a few exceptions, California street dedication cases have disregarded the method of dedication and have held that the public acquires only an easement across a street or highway. ${ }^{41}$

38 Taylor v. Continental So. Corp., 131 Cal. App. 2d 267, 280 P.2d 514 (1955). In allowing mineral exploitation of the park, the court followed an Attorney General's opinion, 19 Ops. CaL. Atr'y GeN. 157 (1952), which found that slant drilling was not prohibited by Public Resources \& 7051 which provides, in part, that: "No land used, owned, dedicated, or acquired hy purchase, condemnation, gift or otherwise as a public park, highway, street, walk, or public playground ... and no land owned ... within 300 feet above the line of high tide, or at any point below the line of high tide, of the Pacific Ocean, or any arm, bay or inlet of the Pacific Ocean shall be leased for the drilling for and production of petroleum products or other minerals."

${ }^{39} \mathrm{It}$ is unlikely that an interested citizen would be willing to assume the expense of a lawsuit and the extensive engineering reports necessary to prove that removal of subsurface minerals would destroy the possibility of future use. Thus, with the exception of physical interference from mining equipment, Public Resources Code $\S 7051$ has been abrogated, and public recreational areas may be destroyed by mineral exploitation. This is clearly in conflict with express legislative policy. See CAI. Gov'T CODE $\$ \S 6950-54$.

40 A recent case, Morse v. E. A. Robey Co., 214 Cal. App. 2d 464, 29 Cal. Rptr. 734 (1963), is illustrative. Property had been dedicated through adverse user by the defendant's predecessor in interest to the public for use as a beach. Defendants were attempting to build a commercial concessions building on the beach. The court held that the municipality had acquired a fee interest in the property and the defendants were ordered to remove their partially completed building. In reaching this conclusion, the court rejected the argument that the express offer and acceptance in Washington Blvd. Beach Co. v. City of Los Angeles, 38 Cal. App. 2d 135, 100 P.2d 828 (1940), and the deed conveyance in Taylor v. Continental So. Corp., 131 Cal. App. 2d 267, 280 P.2d 514 (1955), could be distinguished from dedication by adverse user. Instead, the court considered dedication of a public beach as analogous to dedication of a park. Thus the purpose of the dedication rather than the form is controlling.

41 In fact, the first important California street case, Wright v. Austin, 143 Cal. 236, 76 Pac. 1023 (1904), made no mention of the method of dedication, but held that due to former Political Code $\S 2631$, Cal. Stats. 1883, ch. 10, $\S 1$, at 7 , the public acquired easement rights to the land while the underlying fee interest remained in the owner. Section 2631 provided: "By taking or accepting land for a highway, the public acquires only the right of way and the incidents necessary to enjoying and maintaining the same, subject to the regulations in this and the Civil Code provided." In 1935, this section was amended to apply only to county highways and was reenacted as Streets \& Highways Code $\S 905$. Cal. Stats. 1935, ch. 29, § 905, at 303.

Several district courts of appeal cases which followed Wright v. Austin held that, despite $\S 2631$, a deed grant of land for street or highway use transferred a fee interest to the public. In Cooper v. Selig, 48 Cal. App. 228, 191 Pac. 983 (1920), the court, ignoring $\S 2631$, found that a grant deed of a strip of land for purposes of a public road transferred an absolute fee interest to the public. The phrase "for road purposes" was determined to be 
Upon abandonment of the strip of land by the governing body, the easement merges into the underlying fee and the abutting owner can make use of the land. ${ }^{42}$ Despite the soundness of these decisions, however, the legislature has chosen to interfere, creating uncertainty and confusion. In 1961, to avoid the finding that a mere easement is conveyed when a private owner purports to deed a fee interest to the governing body, the legislature retroactively repealed California Streets and Higliways Code section 905 which provided "By taking or accepting land for a county highway, the public acquires only the right of way and the incidents necessary to enjoy and maintain the same ...."43 In repealing section 905 , the legislature declared that after one year from the date of the repeal no proceeding, action, or defense to prevent a county or city from acquiring fee title by deed or condemnation can be based solely on the

a statement of purpose and not a condition subsequent. Since a municipality cannot abandon lands held by fee title, the abutting owner's ejectment action failed. This decision was followed a few years later by Las Posas Water Co. v. County of Ventura, 97 Cal. App. 296, 275 Pac. 817 (1929), which by general rules of construction interpreted a similar deed to convey a fee interest to the public. Section 2631 was interpreted to mean that by taking or accepting an easement over land for highway purposes the public acquires only a right of way. This is a doubtful interpretation of the statute, but the court was probably correct in assuming that the statute did not apply to a deed conveyance of a fee title in the land. The statute was ignored in Basin Oil Co. of Cal. v. City of Inglewood, $125 \mathrm{Cal}$. App. 2d 661, 271 P.2d 73 (1954), a case closely following Las Posas, in which abutting owners were denied a share of royalty proceeds because a fee title had been deeded to the city. In 1954, the California Supreme Court, in People v. Thompson, 43 Cal. 2d 13, 271 P.2d 507 (1954), settled the matter, loolding that a deed grant of property to the state, by virtue of $\S 2631$ transferred only an easement to the public. The abutting owners were thus awarded a share of condemnation proceeds.

Public officials can maintain an action for ejectment even though the public holds only an easement. See City \& County of San Francisco v. Grote, 120 Cal. 59, 52 Pac. 127 (1898); City of Visalia v. Jacob, 65 Cal. 434, 4 Pac. 433 (1884).

42 See notes 122-23 infra and accompanying text.

43 Cal. Stats. 1961, ch. $1788, \S 3$, at 3803 . In 1955 , the legislature, apparently disagreeing with the holding in People v. Thompson, 43 Cal. 2d 13, 271 P.2d 507 (1954), amended § 905, providing that "this section shall not be construed or applied so as to prevent a county, city and county, or city from acquiring fee title to land for highway purposes." Cal. Stats. 1955 , ch. 1219, $\$ 1$, at 2231. This amendment, however, did not achieve the desired result. Four years later a district court of appeal, in City of Los Angeles v. Pacific Elec. Ry., 168 Cal. App. 2d 224, 335 P.2d 1042 (1959), granted an award in eminent domain to the abutting owners rather than to the county for the taking of a county highway despite the county's having received the road by a deed which was clearly intended to convey a fee title. The court based its decision on an assertion that the general provisions of the Civil Code relating to construction of deeds were overridden by the more specific Political Code $\S 2631$ (see note 41 supra) and Civil Code $\$ 831$ which provides: "An owner of land bounded by a road or street is presuned to own to the center of the way, but the contrary may be sliown." The court lield that the presumption raised by these specific statutes was not rebutted by a grant deed. Since the grant had occurred in 1886, when Pohitical Code $\S 2631$ was controlling, the court refused to permit the 1955 legislative amendment to change the quality of the estate acquired by the public. To do so, said the court, "would sanction retroactive legislation impairing vested rights, and that cannot be done." 
statute. Thus section 905 can be used when the city or county acquired land for highway use other than by deed before the section was repealed.4 Moreover, this legislative declaration implies that if the section is not used alone but is used with other evidence tending to slow that the public acquired only an easement in dedicated lands, the statute will be authoritative as to roads dedicated before its repeal. Therefore, in a case where there is evidence that the donor intended to deed only an easement, an action or defense probably can be based on section 905 .

At the same time, the legislature amended Califorma Streets and Highways Code Section $903^{45}$ which now provides: "After one year from the making of an order by a board of supervisors, pursuant to this division, opening a ligliway over any land, the county acquires title to the land in accordance with the terms of the order." Although this statute is ambiguously worded, it seems to permit county officials to declare what interest the county will acquire in lands dedicated for highway use without regard to the dedicator's intent. Problems could result slould the board of supervisors declare that the county acquires a fee simple interest in a highway when the donor clearly intended to transfer only an easement. Since section 905 was repealed to avoid frustrating the donor's intent, section 903 should not be used to accomplished this very purpose. If the county acquires a fee simple interest, upon abandonment the higlway would not conveniently revert to the abutting owner but would be sold by the county, possibly resulting in third party ownership of a strip of land between two lots. ${ }^{46}$ It slould be noted, also, that the present provisions of section 903 require the donor to wait until the county decides to open the land as a higliway before he discovers what interest he has conveyed to the public. A inore adequately drafted statute would be similar to the California emment domain provisions ${ }^{47}$ wherein the legislature lias clearly histed the interests taken by the public and las given the governing body the option to take a fee simple interest whenever necessary. Sucli a statute slould take into account the donor's intent and sliould provide that upon abandonment by the governing body ownership in the lands reverts to the abutting owner regardless of the interest held by the public.

44 See, e.g., Galeb v. Cupertino Sanitary Dist., 227 A.C.A. 315, 325, 38 Cal. Rptr. 580, 586-87 (1964). The streets in question were dedicated under the provisions of the Subdivision Map Act before the repeal of $\S 905$. The court did not mention that the section was ever repealed. In Richards v. County of Colusa, 195 Cal. App. 2d 803, 806, 16 Cal. Rptr. 232, 234 (1961), dedication of a street by map recordation was found to transfer only an easement to the public. Streets \& Highways Code $\S 905$, however, was not mentioned.

45 Cal. Stats. 1961, ch. 1788, § 1, at 3803.

46 For a discussion of how this problem was encountered in Illinois, see Prall v. Burchkhartt, 299 Ill. 19, 24-26, 132 N.E. 280, 282-83 (1921).

47 See note 36 supra. 


\section{A Legislative Solution}

It is apparent that much confusion and uncertainty endures under common law doctrines of dedication and that much of this disorder and perplexity can be attributed to piecemeal legislative action, often in answer to case law, which has affected many unrelated codes.

One possible solution is enactment of a comprehensive series of statutes covering dedication of lands which are not covered by the Subdivision Map Act. Surely includible would be provisions for quieting title upon non-use by the pubhc, ${ }^{48}$ for rendering the governing body liable for failure to maintain roads accepted by adverse user and substantial city or county repair, and for determining what interest the public acquires once dedication is complete. In addition, there should be a requirement that before leasing dedicated lands for mineral or other exploitation, government officials show clearly that such lands will remain permanently usable. Later legislative additions or amendments would be made to this series of statutes, resulting in greater certainty in the law of dedication.

\section{II}

\section{STATUTORY DEDICATION}

\section{A. Introduction}

Statutory regulation of land dedication in Cahfornia has emerged from the increasing need for economic and environmental control of subdivision development. Many problems have accompanied California's rapid suburban growth, ${ }^{40}$ including the need for additional municipal facilities such as streets, sewers, parks, and schools, as well as the need for local planning controls which will insure the creation of attractive communities. The California Subdivision Map Act, enacted in 1937,50 was designed to cope with such problems.

The Map Act is a comprehensive set of statutes intended to regulate

48 See text accompanying notes 133-135 infra. Code of Civil Procedure $\$ 748.5$ now applies only to dedication by map. Corey v. City of San Diego, 163 Cal. App. 2d 65, 71, 329 P.2d 99, 103 (1958). There slould be provisions for other types of dedication as well. Perhaps a period shorter than 25 years would be justifiable if the private landowner should make good faith improvements on public land.

49 Because of the rapid rate of population growth in California, 4000 new homes are needed each week. Car. Sevate Intertar Comar. on Subdivision Deveropment \& Planning, 3 Appendix to Journal of the Senate, Reg. Sess. 5 (1957). The value of new subdivisions processed by the state Division of Real Estate in 1955, was approximately $\$ 40,000,000$ a week or $\$ 2$ billion a year. Moreover, subdivision development has become an added impetus to the general economy by creating employment opportunities and by stimulating production of building materials. See Car. Senate Internm Comm. on Subdivision Developarent \& Planning, 3 Appendix to Journal of the Senate, Reg. Sess. 5 (1955).

50 Cal. Stats. 1937, ch. 670, at 1863, as amended Stats. 1939, ch. 155, at 1377; Stats. 1941, ch. 537, at 1857 (now CaL. Bus. \& Prof. Code $\$$ 11500-641). 
all aspects of subdivision development, including the dedication of land to public use. The Act specifies which lands the subdivider must dedicate to the governing body and describes additional requirements the governing body may impose on the subdivider as a condition to approval of the development. Since the Map Act is merely an enabling statute for local supervision, regulation is on the local level..$^{\mathbf{5 1}}$ Thus local ordinances not inconsistent with the Map Act may be enacted to prescribe the standards and procedures whicl must be followed should a subdivider wish to dedicate streets and parks to the public; $;^{52}$ criminal sanctions are imposed for failure to comply with its procedures. ${ }^{53}$ By allowing local governments to control the improvement and design of new subdivisions, it was hoped that the primary objectives of the Act would be achieved-the coordination of new subdivision designs with those of the community and the assurance that lands dedicated to the public are imitially improved by the subdivider so as to avoid an undue burden on the taxpayer. ${ }^{54}$ Since the provisions of and ordinances under the Subdivision Map Act are applicable only to lands offered for dedication subsequent to the Act's adoption in $1937,{ }^{55}$ subdivision lands offered for dedication prior to 1937 are governed by the provisions of old map acts ${ }^{56}$ or by the rules of common law dedication. Should statutory dedication fail, the lands may nonetheless be transferred to the public if the requirements of common law dedication are satisfied..$^{57}$

\section{B. Dedication Procedure Under the Subdivision Map Act}

Since the developer of a new subdivision is responsible for the maintenance of the subdivision streets until they have been dedicated to the city or county, and since it is unlawful to sell subdivision lands without compliance with the Map Act, it is important that the developer be familiar with statutory dedication procedure. ${ }^{58}$ The initial step in the

\footnotetext{
51 See Cat. Bus. \& Prof. Code $\$ \S 11525,11526$.

52 See Cax. Bus. \& Prof. Code $\$$ 11506, 11590.

53 See Cat. Bus. \& Prof. Code \$§ 11538, 11541.

54 Cal. Senate Internar Conar. on Subdivision Development \& Planning, 3 AppendIX to Journat of tHe Senate, Reg. Sess. I5 (1955).

55 McKinney v. Ruderman, 203 Cal. App. 2d 109, 116, 21 Cal. Rptr. 263, 267 (1962); Quacchia v. County of Santa Cruz, 164 Cal. App. 2d 770, 771, 331 P.2d 216, 217 (1958).

56 E.g., Cal. Stats. 1929, ch. 837, at 1790; Cal. Stats. 1907, ch. 231, at 290; Cal. Stats. 1893 , ch. 65, at 96. See also Cat. Bus. \& Prof. Code $\$ 11538$ (b).

57 See City of Sacramento v. Jensen, 146 Cal. App. 2d 114, 303 P.2d 549 (1956), in which the failure to meet the requirements of an old map act did not prevent subsequent dedication under the doctrines of common law dedication.

58 In order for dedication to be effective the parties must substantially comply with the provisions of the statutes and ordinances. Compare People v. Rio Nido Co., $29 \mathrm{Cal}$. App. 2d 486, 492, 85 P.2d 461, 465 (1938), with Galeb v. Cupertino Sanitary Dist., 227 A.C.A. 315, 323-24, 38 Cal. Rptr. 580, 586 (1964).
} 
development of a subdivision ${ }^{59}$ is the preparation of a tentative map ${ }^{60}$ showing the general design of the proposed subdivision and the physical conditions existing in and around it. ${ }^{61}$ This map, accompanied with other data required by local ordinance, is filed with the advisory agency or governing body having jurisdiction over the land, which, within forty days after the map has been filed, must approve, conditionally approve, or disapprove the map of the subdivision. ${ }^{62}$ Local ordinances may set up requirements relating to the design and improvement of the subdivision as a condition of approval, ${ }^{63}$ but if there is no local ordinance, the agency may require only that streets and drainage ways be properly located and of adequate width. ${ }^{64}$ Should the subdivider be dissatisfied with the advisory agency's decision or recommendation, he may appeal to an appeal board, ${ }^{65}$ then to the governing body, ${ }^{66}$ and finally to the superior court. ${ }^{67}$ After approval of the tentative map, the subdivider must prepare a final survey map of the proposed subdivision. ${ }^{68}$ Should the subdivider desire to dedicate any lands, he must secure a certificate, signed and acknowledged by all persons having any interest in the lands, offering these lands to the public for specified uses, and indicating any

59 Business \& Professions Code $\S 11535$ (a) defines a subdivision as "any real property, improved or unimproved, or portion thereof, shown on the latest adopted county tax roll as a unit or contiguous units, which is divided for the purpose of sale or lease, whether inmediate or future, by any subdivider into five or nore parcels . . . "

00 Cal. Bus. \& Prof. Code \& 11550.

01 Cal. Bus. \& Prof. Code § 11503.

62 Cat. Bus. \& Prof. COde $\S 11552$.

63 Sec CaL. BUS. \& Prof. Code $\$ 11525$. See notes 81-97 supra and accompanying text. 64 Cal. Bus. \& Prof. Code \& 11551.

65 CaL. Bus. \& Prof. CODE $\S 11552$. The appeal nust be within 15 days, and the agency must hear the appeal within 15 days. The term "appeal board" is defined by $\S 11512$ as "a board or other official body designated by local ordinance to bear and make determinations upon appeals fron actions of the advisory agency with respect to tentative subdivision maps, or the kinds, nature and extent of the improvenuents recommended by the advisory agency to be required."

66 Cax. Bus. \& Prof. Code $\S 11552$. The appeal must be within 15 days, and the governing body must hear the appeal within 15 days.

${ }^{67}$ CAI. Bus. \& Prof. Code $\$ 11525$. The proceeding must be commenced within 90 days after the decision of the governing body. It takes precedence over all matters except criminal, probate, eminent domain, forcible entry, and unlawful detainer.

One case, Shorb v. Barkley, 108 Cal. App. 2d 873, 240 P.2d 337 (1952), held that when a local ordinance requires that the planming commission must upon approval of the tentative map designate required improvements, and when the commissioners with all the facts before then require certain improvements, the county surveyor cannot later require other inprovements. This rule should apply in all cases when the subdivider has begun development work in rehance on the planning agency holding. See also CAL. Bus. \& Prof. CoDE § 11611, which provides that final map approval depends upon fulfillment of requirements "applicable at the time of approval of the tentative map."

08 Cad. Bus. \& Prof. CODE \& 11554. The requirenents, form, and contents of the map are prescribed by $\$ \S 11565,11567$. 
reservations. The certificate may also state that any specified parcel is not offered for dedication, although a local ordinance may require as a condition of approval that any parcels intended for public use be offered for dedication. ${ }^{69}$

Once the final map and the required certificates are complete, they must be filed with the governing body, which within ten days inust approve the map if it conforms to the requirements of the Subdivision Map Act and any applicable local ordinance. At this time, the governing body must also accept or reject all offers of dedication and must, as a condition precedent to the acceptance of any streets, provide that the subdivider improve or enter an agreement to improve the streets at his own expense. As an alternative, the subdivider may be allowed to contract with the governing body to proceed under an appropriate special assessment act for financing the streets. ${ }^{70}$ After sucli an agreement or contract is made, and the subdivider has posted an improvement security, the accepted map is recorded ${ }^{71}$ and title to the dedicated property passes to the city. ${ }^{72}$

To provide the governing body with a means of postpoming acceptance of lands offered for dedication until they are needed, the Subdivision Map Act makes a substantial change in the cominon law requirement of offer and acceptance. Under the common law doctrine of dedication, an offer may be expressly or impliedly revoked by the dedicator at any time before it is accepted; however, when lands are offered for dedication under the Map Act, if the governing body sliould reject the offer of any streets or other ways, the offer is not thereby terminated, and the governing body inay at a later date rescind its rejection and accept the streets or ways. This perpetual right of acceptance can be terminated only by statutory abandonment, by approval of a resubdivision of the lands by

69 Since, under Business \& Professions Code $\$ 11590$, public use of streets not offered for dedication under the Subdivision Map Act is permissive, they may not be dedicated by adverse user. See City of Eureka v. Croghan, 81 Cal. 524, 22 Pac. 693 (1889). See also CAL. Crv. CODE $\S 813$, which provides for recordation by a landowner of a notice that public use of his land is permissive only.

Section 11590 also provides that a waiver of access rights from any abutting property onto any street or highway may be included in the offer, but the governing body may not require such a waiver as a condition precedent to the approval of the final map.

70 Cax. BUS. \& ProF. Code $§ 11611$. Improvement standards must be available in book or pamphlet form for public examination in the office of the clerk of the local agency. See also Cominent, 53 CAIIF. L. REv. 364 (1965).

71 CAL. Bus. \& Prof. CODE § 11614. The improvement security is required as security for the faithful performance of street and drainage improvements which may be required of the subdivider as a condition precedent to the acceptance of his streets. The improvement security may be a cash deposit, a bond by a corporate surety, or an instrument of credit by a financial institution. CAL. Bus. \& Prof. Code $\S 11612$.

72 Cat. Bus. \& Prof. Code § 11615. 
the filing of a new subdivision map, or by approval of a reversion of the lands to acreage by the withdrawal of the subdivision map. ${ }^{73}$

\section{Territorial Jurisdiction}

Questions often arise as to when and to what extent a city or county can influence the approval of a subdivision map or the acceptance of lands dedicated outside its boundaries. For example, an attractive subdivision with curved streets and concomitant slow and sparse traffic may exist within, but on the borders, of city $A$. Should the owner of adjacent lands in city $B$ file a tentative subdivision map with the advisory agency of city $B$, city $A$ may want to know whether it can compel city $B$ to require that the subdivider dedicate streets conforming to those dedicated within the borders of city $A$.

Of course, lands within the boundaries of one city or county which are offered for dedication cannot be accepted by the public officials of another city or county. ${ }^{74}$ Under the Subdivision Map Act, lowever, if a subdivider is developing land outside the boundaries of any city and wishes to have his subdivision annexed by that city, he may file a tentative map with the governing body, and the city may approve the map on condition that the property in fact be annexed to the city. ${ }^{75}$ Moreover, cities and counties may inspect and make recommendations concerning subdivision maps outside but adjacent to and within three miles of its border. ${ }^{76}$ These recommendations must be "taken into consideration" by the governing body having jurisdiction. ${ }^{77}$ Tlus, municipalities and counties can to some extent regulate and control the dedication of lands outside but near their borders, ${ }^{78}$ but it is unclear what recourse a governing body has should an adjoining city or county dismiss or ignore its proposals. It appears that a governing body can appeal the reasonableness of a dismissal of its recommendations to a court of general jurisdiction, although this right is not clearly given by the Subdivision Map

73 Car. Bus. \& Prof. Code § 11616.

74 Miller v. Fowle, 92 Cal. App. 2d 409, 206 P.2d 1106 (1949). The court pointed out that acceptance of an offer of dedication creates an obligation to maintain and repair, and that the city was empowered by its charter to maintain only those streets located within its boundaries. Business \& Professions Code $\$ 11527$ provides that a county has no jurisdiction to approve a map of subdivided lands lying outside its unincorporated area and, similarly, a city may approve a map only of those subdivided lands that he within its incorporated area. But see CAL. PUB. REs. CODE § 5157.

75 Cal. Bus. \& Prof. CODE § 11531.

76 CAL. Bus. \& Prof. CODE § 11528.

77 Ibid.

${ }^{78}$ In addition, Business \& Professions Code $\$ 11528.1$ provides that the Department of Public Works may make recommendations concerning the effect of state highways on proposed subdivisions. 
Act. ${ }^{78}$ It would be desirable, therefore, to include a provision in the Map Act unmistakably giving both cities and counties the right to appeal to the superior court the dismissal of any recommendations. If the dismissal is found to be unreasonable, the court could require that the recommendation be accepted, thus preventing an arbitrary borderline from creating an undesirable lack of uniformity in the lands dedicated and the neighborhood developed.

\section{Control of Subdivision Development by Conditional Approval of the Subdivision Map}

Within the past few years, much lias been written about control of subdivision development. ${ }^{80}$ These articles have exhaustively discussed the numerous procedures open to a governing body for regulating the development of neigliborlioods and for insuring that the initial improvement expense of dedicated lands be assumed by the subdivider or by the residents of the new subdivision. There are areas, however, where California legislation is needed.

In addition to various zoning requirements, ${ }^{81}$ local governnients have attempted to control subdivision development either by requiring that certain lands be dedicated or improved by the subdivider, or by requiring that the subdivider or homeowner pay a fee to cover certain improvement expenses as a condition precedent to approval of the subdivision

79 Business \& Professions Code $\S 11525$ provides that any decision by a governing body concerning the design and improvement of a subdivision is subject to court review as to its reasonableness. Any subdivider or person claiming to be aggrieved by the decision has 90 days within which to bring an action in the superior court. The tern "person" would seem to include a mumicipal corporation, cf. CaL. Civ. Code § 14; Cat. Code Civ. Proc. § 17, but it does not seem to include a county. The statute was written with a subdivider or private landowners in mind, rather than a city or county. It shall be noted, also, that $\S 11525$ gives a right to contest only those decisions concerning the "design and improvement" of subdivisions. Wine v. City of Los Angcles, 177 Cal. App. 2d 15\%, 16\%, 2 Cal. Rptr. 94, 101 (1960).

Should the city or county be unable to proceed under $\S 11525$, perhaps the private landowners affected by the rejected proposals could sue, contending that unless the proposal is accepted the market value of their property will decline. Cf. Thal v. County of Santa Cruz, 204 Cal. App. 2d 645, 22 Cal. Rptr. 637 (1962).

${ }^{80}$ E.g., Cutler, Legal and Illegal Methods for Controlling Community Growth on the Urban Fringe, 1961 Wis. L. REv. 370; Delehant, Representing the Land Developer: Step by Step Techniques, 40 Ner. L. Rev. 330 (1960); Heyman \& Gilhool, The Constitutionality of Imposing Increased Community Costs on New Suburban Residents Through Subdivision Exactions, 73 YALE L.J. 1119 (1964); Reps, Control of Land Subdivision by Municipal Planning Boards, 40 CoRNerr L.Q. 258 (1955); Reps \& Smith, Control of Urban Land Subdivision, 14 Syracuse L. Rev. 405 (1963); Smith, The Dilemma Faced by Municipalities in Controlling Nearby Land Developments, 40 NEB. L. REv. 318 (1960); Taylor, Current Problems in California Subdivision Control, 13 Hastings L.J. 344 (1962).

81 E.g., Roney v. Board of Supervisors, 138 Cal. App. 2d 740, 292 P.2d 529 (1956) (zoning ordinance controls land use with same dignity as Subdivision Map Act). 
map, ${ }^{82}$ or as a condition precedent to acceptance of the subdivider's streets. ${ }^{83}$ In testing the validity of these techniques, two questions must be answered: Whether the requirements are authorized by legislation; ${ }^{84}$ and, whether the requirements are constitutional, ${ }^{85}$ that is, has property been taken without compensation or has there been denial of equal protection of the laws. A local ordinance may require that a parcel, shown on the final map, which is intended for any public use must be offered for dedication, ${ }^{86}$ but, with a few exceptions, ${ }^{87}$ the Map Act does not authorize the exaction of a fee as a condition to approval of the map. Thus it has been held that the requirement of a general fee as a condition precedent to the approval of a subdivision map is illegal because it is not authorized under the Map Act ${ }^{88}$ unless the exaction is a business tax covermg the entire subdivision operation, or a reasonable charge for a service rendered, such as a sewer hook-up, ${ }^{80}$ or a construction charge. ${ }^{90}$ Therefore, unless the Map Act is amended to provide for compulsory payment of a fee, local governments are restricted to the technique of requiring that the subdivider donate and improve certain lands, the question becoming what sort of lands the subdivider may legally and constitutionally be required to dedicate.

It should be remembered that cities and counties may enact local ordinances consistent with the Subdivision Map Act regulating the design and improvement of subdivisions. "Design" refers to the align-

82 Any sale or contract to sell subdivision land without approval and recordation of the final map is unlawful. See CaL. Bus. \& Prof. Code $\$$ 11538, 11541.

83 See notes 101-08 infra and accompanying text.

84 In California, regardless of the procedure used, a governing body is limited by the provisions of the Subdivision Map Act and the local ordinances enacted pursuant to it. See Car. Bus. \& Prof. Code $\S \S 11505,11525 ; 23$ Ors. Cax. Axt'y Gen. 223, 225 (1954).

85 See generally Heyman \& Gilhool, The Constintionality of Imposing Increased Community Costs on New Suburban Residents Through Subdivision Exactions, 73 YALE L.J. 1119 (1964). In this article the constitutional requirements which a method of subdivision control must satisfy are exhaustively covered.

86 Cat. Bus. \& Prof. Code $\$ 11590$.

87 E.g., CAL. Bus. \& Prof. CODE $\S 11543.5$ (cost to construct planned, surface drainage facilities).

88 Newport Bldg. Corp. v. City of Santa Ana, 210 Cal. App. 2d 771, 26 Cal. Rptr. 797 (1962); Kelber v. City of Upland, 155 Cal. App. 2d 631, 318 P.2d 561 (1957). In neither case did the court discuss the constitutionality of a requiring a fee as a condition precedent to map approval, but the court did say that the purpose of the Map Act is to provide for regulation and control of the design and improvement of a suhdivision with consideration of adjacent areas, and not to provide funds for the benefit of the entire city. Thus it was suggested that, should the Map Act be amended to allow the exaction of a fee, the fee would have to be reasonable and proper, and for the benefit of the subdivision, or to compensate adjacent areas for any increased burden on their facilities.

900 (1960).

${ }^{89}$ Longridge Estates v. City of Los Angeles, 183 Cal. App. 2d 533, 6 Cal. Rptr.

90 City of Buena Park v. Boyar, 186 Cal. App. 2d 61, 8 Cal. Rptr. 674 (1960).

91 See note 84 supra. 
ment, grades, and widths of streets and sewers, and to minimum lot area and width; ${ }^{92}$ "improvement" refers to street work and utilities necessary for the general use of subdivision lot owners and local neighborhood traffic. ${ }^{93}$ Thus when an ordmance provides that a goverming body may require the dedication of a certain parcel as a condition to approval of the subdivision, the validity of the ordinance depends upon whether the local ordmance is consistent with the definition of "design" and "improvement."

The California Attorney General in a recent opinion ${ }^{94}$ stated that an ordinance could require that a subdivider dedicate curved rather than straight streets, if such a requirement were not based solely on aesthetic considerations. The requirement would be authorized by the Map Act because it controls street "alignment"; the requirement would be constitutional because by slowing local neighborliood traffic it tends to make the subdivision safer for the residents.

The attorney general's opinion was based on a California Supreme Court decision, Ayres v. City Council of Los Angeles. ${ }^{95}$ In Ayres, the court upheld the city's requirement that a subdivider dedicate a ten-foot strip of land for widening an abutting highway, an additional ten-foot strip for tree and shrubbery planting and for preventing ingress and egress between the lots and the highway, a twenty-foot parcel for widening another street, and another portion of land for elimination of a traffic hazard. The court's reasoming is somewhat ambiguous, but the requirements were considered consistent with the Map Act because they were related to the planning of "neighborhood traffic" conditions; the requirements were not considered a taking without compensation because the landowner actually benefited by the improved design and by rehef from the burden of improvement. It was no defense that the city as a whole liad also benefited.

It is clear, then, that in California a governing body can require that a subdivider dedicate certain lands related to the design and improvement of various sewage and drainage easements and lands related to local neighborhood traffic conditions. A city or county, however, may not require dedication of recreational or school lands. It could be argued that the ten-foot strip required for tree and shrubbery planting in Ayres is analogous to a park or recreational area, but the California Attorney General lias pointed out that the parcel was related directly to the control

92 Cat. Bus. \& Prof. Code § 11510.

93 CaL. Bus. \& Prof. $\S 11511$. If there is no local ordinance, the governing body may require only the proper location and adequate width of streets and drainage ways. Cal. Bus. \& Prof. Code $\S 11551$.

9443 Ozs. CaL. Atr'y Gen. 89 (1964).

9534 Cal. 2d 31, 207 P.2d 1 (1949). 
of neighborhood traffic, and that the Map Act does not expressly authorize the compulsory dedication of park or school lands. ${ }^{96}$ Clearly the terms "design" and "improvement" as defined in the Act do not comprehend recreational or school areas. Compulsory dedication of these lands would, therefore, most likely be found by the courts to conflict with rather than to supplement the Map Act. ${ }^{97}$ This situation is unfortunate. Adequate recreational areas and school lands are as essential to the formation of an attractive and utilitarian neighborhood as are adequate streets and sewers. Admittedly, the city or county may purchase these lands from the subdivider, ${ }^{98}$ the tax burden falling on the entire community rather than on the residents of the subdivision who would benefit from the purchase. A primary objective in control of subdivision development, however, is to place the burden of the initial cost for school and recreational lands on the subdivider who will in turn pass these costs on to the subdivision residents who benefit from the improvements.

The answer may be an amendment to the Subdivision Map Act allowing the local governing body to require that a subdivider dedicate sites for recreational areas and school sites in accordance with a master plan designed to benefit the subdivision residents. ${ }^{99}$ Of course, care must be taken to avoid denial of equal protection of the laws by arbitrary taking of these lands; there must be no discrimination between land developers, and the amount of land required must relate to the number of new residents who will be using the land. Moreover, the required dedication must be imposed reasonably in contemplation of the character of

9629 Ops. Cat. AtT'y Gen. 49 (1957); 22 Ops. CaL. Atr'y Gen. 168 (1953).

97 It is possible that a subdivider, who desires for business reasons to expedite the approval of his final map, may "voluntarily" donate park or school lands in accordance with the suggestion of the governing body. See Oakland Tribune, March 28, 1965, p. 1-C col. 5. It seems that in such a situation the subdivider could later bring an action to compel return of, or payment for, this property. See Newport BIdg. Corp. v. City of Santa Ana, 210 Cal. App. 2d 771, 778-79, 26 Cal. Rptr. 797, 801-02 (1962). Since the delay in appealing the governing body's unauthorized demand would result in a loss of money to the subdivider, problems of extortion could arise. See CAL. PEN. Code \& 518.

98 Under the Code of Civil Procedure $\S 1238(3)$, a governing body is authorized to acquire park lands by eminent domain. See also CaL. Gov't Code \$§ 6953, 25353; CAL. Pub. Res. Code $\S 5301$.

${ }^{90}$ See generally Assembly Interim Subcommittee on Municipal and County Government Hearing on Neighborhood Parks and Open Space in Subdivisions (1964). The proposed amendment becomes increasingly desirable as subdivision development based on various schemes of cluster zoning become more popular. Protection of open spaces in these developinents by the use of restrictive covenants and owners' associations can be supplemented by dedication of a development or contractual right to the city or county, allowing the governing body to protect the lands should the private arrangements fail. A city or county may accept a gift of a development right, easement, covenant, or other contractual right in an open area whose natural condition would enhance the value of abutting or surrounding urban developments. CAI. Gov'T CODE $\S \S 6953-54$. 
the neighborhood and the health, safety, and general welfare of the residents. Often it can be shown that other residents in the community will make use of and benefit from the new subdivision school or recreational lands; however, fee assessments calculated by a technique of cost accounting in lieu of compulsory dedication is a possible answer to the problems posed in assuring that new subdivision residents and other residents of the community pay their proportionate share for new facihties. ${ }^{100}$

\section{E. Control of Subdivision Development by Conditional Acceptance of Dedicated Lands}

As an alternative to controlling subdivision development by conditional approval of the subdivision map, the governing body may set up certain requirements as a condition to acceptance of subdivision streets. Since the subdivider will be anxious to dedicate his streets and thus rid himself of the maintenance responsibitity and expense, and since the local government will be doing the subdivider a service by accepting the streets, the question arises as to what acts a city or county may or should require of the subdivider as a condition precedent to the acceptance of his streets.

Section 11611 of the Cahfornia Business and Professions Code provides that a governing body shall at the time it approves the final map accept or reject all offers of dedication and as a condition precedent to the acceptance of any streets or easements provide for their improvement by the subdivider. Under the present provisions of the Map Act, however, a requirement that the subdivider perform any acts other than those relating to improvements of the streets would be inconsistent with the Act and thus would be unauthorized. A local ordinance could not, for example, require that the subdivider dedicate school lands or donate money to a school fund as a condition precedent to the acceptance of his streets. Moreover, under the present Act, the subdivider is informed of all the requirements which must be fulfilled in order to achieve final dedication of his streets before he has begun any work on the subdivision. ${ }^{101}$ Thus the governing body caunot stand by while the developer expends great sums of money in building and selling homes and in improving street and drainage ways and then impose additional requirements as a condition precedent to acceptance of his streets.

Should the Map Act be amended to enable governing bodies to require acts other than street improvement as a condition precedent to acceptance of the streets, problems could arise. First, the required acts 
would have to satisfy the usual constitutional requirements--they could not constitute an arbitrary and unreasonable taking without compensation, nor could they result in a denial of equal protection of the laws; the requirements must apply to all subdividers in proportion to the financial burden placed on the city or county by the creation of their subdivision, and they must relate to the character of the neighborhood and the general welfare of the residents. ${ }^{102}$

In addition to the constitutional hmitations, there are financing problems which must be met if a governing body desires to use conditional acceptance of streets as a means of subdivision control. Refusal to accept a subdivision map unless certain conditions are fulfilled leaves the subdivider with the choice of fulfilhing the desired requirements, or of leaving his lands undeveloped. ${ }^{103}$ Conditional acceptance of the dedicated lands and simultaneous approval of the final map, on the other hand, leaves the subdivider free to develop and sell lots or homes to private purchasers. These private purchasers can reasonably expect that once the subdivision streets are improved they will be maintained by the local government, but should the subdivider fail to donate to the school fund or fulfill other conditions precedent to the acceptance of his improved streets, the governing body could not be compelled to accept the streets, ${ }^{104}$ and the burden of nuaintenance might fall on the adjacent owners. In fact, under Section 831 of the California Civil Code, the abutting owner is presumed to own a fee interest to the center of the street. Once the subdivided land is sold, the developer retains no legal interest in the streets; the purchasers acquire a fee interest to the center of the road. ${ }^{105}$ The only remedy would be a suit by the governing body for specific performance or damages for breach of the subdivider's agreement to improve. ${ }^{106}$ Should the subdivider become insolvent, the condition precedent to acceptance might never be fulfilled. The purchasers should not be subjected to this risk.

102 See Heyman \& Gilhool, supra note 85.

103 Under Business \& Provisions Code $\S \S 11538,11541$, it is a misdemeanor to sell or lease or to contract to sell or lease subdivision lands without compliance with the Map Act and without recordation of the final map. See County of San Mateo v. Palomar Holding Co., 208 Cal. App. 2d 194, 24 Cal. Rptr. 905 (1962); 27 Ors. CAI. Atr'y GeN. 66 (1956); see also Pratt v. Adams, 229 A.C.A. 704, 40 Cal. Rptr. 505 (1964).

104 See County of Kern v. Edgemont Dev. Corp., 222 Cal. App. 2d 874, 35 Cal. Rptr. 629 (1963).

105 Brown v. Bachelder, 214 Cal. 753, 7 P.2d 1027 (1932); Gross v. City of San Diego, 125 Cal. App. 238, 247-48, 13 P.2d 820, 824 (1932); Ferguson v. Oildale Mut. Water Co., 78 Cal. App. 74, 248 Pac. 256 (1926).

106 See, e.g., County of Los Angeles v. Margulis, 6 Cal. App. 2d 57, 44 P.2d 608 (1935). See also Morro Palisades Co. v. Hartford Acc. \& Indem. Co., 52 Cal. 2d 397, 340 P.2d 628 (1959), in which a private lot owner was not allowed to sue on a surety bond either as an assignee of the county or as a third party beneficiary. 
Thus, under the present provisions of the Map Act if the governing body requires as a condition precedent to the acceptance of any streets or easements that the subdivider improve these streets or easements, the governing body must also require that the agreement or contract to improve be secured by a good and sufficient improvement security, including a cash deposit or a bond. ${ }^{107}$ If conditional acceptance of dedicated streets is used to enforce other requirements such as dedication and improvement of school or recreational lands, similar security arrangements would be necessary. Clearly, a simpler and less risky technique would be a requirement that the subdivider offer school and recreational lands for dedication before approval of the final map, and a later assessment by the governing body of the residents benefited by the facilities for the construction of school and recreational facilities. ${ }^{108}$

\section{F. Conditional Acceptance of Lands to Avoid Tort Liability and Maintenance Responsibility}

Prior to its amendment in 1963, Section 11611 of the California Business and Professions Code provided that a governing body "shall, 109 as a condition precedent to the acceptance of any streets or easements, require that the subdivider, at his option, either improve or agree to improve the streets or easements ...." The purpose of this statute was to reheve the public from the financial burden of initial subdivision street

${ }^{107}$ See Car. Bus. \& Prof. Code $\S 11612$. Because of the frequent inability of subdividers to pay for materials purchased for street improvement, see, e.g., Morro Palisades Co. v. Hartford Acc. \& Indem. Co., 52 Cal. 2d 397, 340 P.2d 628 (1959); Weber v. Pacific Indem. Co., 204 Cal. App. 2d 334, 22 Cal. Rptr. 366 (1962); Evola v. Wendt Constr. Co., 170 Cal. App. 2d 21, 338 P.2d 498 (1959), the section was amended in 1963, Cal. Stats. 1963, ch. $340, \S 1$, to protect contractors as well as the governing body. See generally 38 CAI. S.B.J. 626 (1963). Apparently the individual lot owners are still not protected by the surety. See Morro Palisades Co. v. Hartford Acc. \& Indem. Co., supra.

108 See Heyman \& Gilhool, supra note 85, at 1146. As the article points out, a special assessment must increase the value of the property assessed, but a legislative determination is usually considered conclusive as to whether the property assessed is benefited. The benefit derived from the improvement rather than the distance of the property from the improvement is decisive. Owing to a 1963 amendment, Business \& Professions Code \$ 11611 has provided for a contract between a subdivider and the county to initiate a special assessment for intial subdivision street improvement. A similar provision could be made for park lands and other open spaces.

109 Amended in 1949, Cal. Stat. 1949, ch. 1080, \& 1, at 1982, from "may" to "shall" to insure that the governing body will always place the initial expense of improvement on the subdivider. The amendment may also serve to prevent the defrauding of persons who purchase lots in a subdivision. In Hocking v. Title Ins. \& Trust Co., 37 Cal. 2d 644, 234 P.2d 625 (1951) it was held that the remedy for the failure of a city to obtain an agreement and a bond for improvement of subdivision streets is not an action against the insurers of the title because the lack of streets does not affect the inarketability of title but merely impairs the value of the property. The proper action would be a writ of inandamus to compel the city to fulfill its statutory obligation by requiring that the subdivider improve the streets. 
construction, but it was ambiguously worded so as to induce some unintended results. For example, in Hoover v. County of Kern, ${ }^{110}$ a land developer submitted a final subdivision map to the county board of supervisors which approved the map and accepted all lands offered for dedication. Concurrently with the approval of the map, the subdivider, as consideration for the acceptance of his streets, entered a contract agreeing to improve the streets. Two years later, after the work was completed but several months before the county gave its final approval to the work, the plaintiff was injured when her automobile struck a depression in one of the newly constructed streets. The plaintiff sued both the subdivider and the county. A judgment for the county on demurrer was upheld by the district court of appeals on the ground that section 11611 prevented the board of supervisors from accepting the streets other than conditionally. Thus, section 11611 nullified a formal acceptance of dedicated lands, and the political subdivision was able to avoid liability for maintenance of the dedicated streets until it decided or the subdivider compelled it to approve the improvement work. 111

It seems clear from the form of the contract used in Hoover that the parties assumed that the streets had been accepted and that the subdivider had agreed to improve them. The court, however, ignored the provision in section 11611 allowing a subdivider to "agree to improve" the streets as a condition precedent to acceptance by the governing body. In 1963, the California legislature amended section $11611,{ }^{112}$ so that it now declares that the goverming body shall as a condition precedent to the acceptance of any streets provide for their improvement "by requiring the subdivider $(a)$ to improve said streets . . . at the subdivider's expense, prior to the acceptance thereof, $(b)$ to enter into an agreement with the

110118 Cal. App. 2d 139, 257 P.2d 492 (1953).

111 In County of Kern v. Edgemont Dev. Corp., 222 Cal. App. 2d 874, 35 Cal. Rptr. 629 (1963), the defendant, in consideration of the acceptance of his streets, agreed to construct and improve the streets and to install a water supply system. The street work was completed and was found by the county officials to be satisfactory, but since the water supply system was not installed, the county did not accept the street work. The following spring the water system was found by the county to have been satisfactorily installed, but since the street work had deteriorated from lack of maintenance during the winter, the streets were not accepted. The defendant refused to do the repair work. The county completed the work, accepted the street and water improvements, and sued the defendant for breach of contract. The court held that since the subdivider had not complied with a complex ordinance providing for partial acceptance of improvement work, the streets had not been dedicated to the county, and, even though the contract provided only for initial improvement of the streets, the subdivider was liable for their maintenance until they were taken over by the county. As dicta, the court stated that had a proper applicaion for acceptance in accordance with the local ordinance been refused, the subdivider could have brought a special proceeding in the superior court to determine the reasonableness of the refusal. See CaI. Bus. \& Prof. Code § 11525.

112 Cal. Stats. 1963, ch. 340, §1. 
city or county ... to thereafter improve said streets ... at the subdivider's expense, or $(c)$ to enter into a contract with the city or county ... to thereafter initiate ... proceedings under a special assessment act ...."113 A subdivider and a governing body may now, under provision (b) above, make an agreement similar to that which the parties in Hoover intended to make; however, in liglit of Hoover, should the city or county provide for street or other improvements under provision $(a)$ and require that the construction work be satisfactorily completed before the streets are accepted, the prudent subdivider will carry adequate tort liability insurance until the work is approved and the streets are officially accepted, and he will become thoroughly familiar with the local ordinance requirements for consummation of partial dedication ${ }^{114}$ as the work progresses.

The best solution is a harmonious and cooperative relationship between developer and governing body. Before the subdivider begins work, he should be given a complete and final list of all the conditions which must be fulfilled before his map will be approved or his streets accepted, and he should become familiar with the local ordinances governing the methods of dedicating his streets.

\section{G. Interest Acquired by the Public}

As with lands transferred to the public under the doctrine of common law dedication, it is frequently necessary to deterinine the interest acquired by the public in lands dedicated in comphance with the Subdivision Map Act. The Map Act is silent on the subject, declaring only that "title to property the dedication of which is accepted shall not pass until the final map is recorded ...."115 Thus the public acquires the same interest in lands dedicated under the Map Act as it does at common law. ${ }^{116}$

Since in Cahfornia the public acquires only an easement in dedicated streets, problems have arisen as to the priority, scope, and extent of such

113 Cal. BUS. \& Prof. Code $§ 11611$. (Emphasis added.)

114 See note 111 supra.

115 Cal. Bus. \& Prof. Code § 11615.

116 See notes $35-47$ supra and accompanying text. Unlike common law dedications, however, all streets offered for dedication under the Map Act must be expressly accepted or rejected by the governing body. See CaL. Bus. \& Prof. Code $\$ \$ 11611,11614,11615$. Thus a county cannot use Streets \& Highways Code $\$ 941$, which provides that no county shall be "liable for failure to maintain any road unless and until it has been accepted into the county road system by resolution of the board of supervisors," to avoid liability for failure to maintain any road it has accepted in accordance with the provisions of the Map Act. Similarly, the protection afforded cities under Streets \& Highways Code $\S 1806$ would be lost as to lands accepted under the Map Act. See notes 30-34 supra and accompanying text. 
an easement. In Airways Water Co. v. County of Los Angeles, ${ }^{117}$ for example, subdivision landowners had granted an easement to the plaintiff company for water mains. The mains were installed in conformity with a street plan proposed by the county road department so that they would not be disturbed by street improvements. The landowner then dedicated an easement in the subdivision streets to the county in accordance with the Subdivision Map Act. Later, the proposed street plan of the road department was changed, and it became necessary to relocate the water mains because they interfered with street paving operations. The water company sued for the cost of relocation, claiming easement rights superior to those acquired by the county. The court ${ }^{118}$ held that while the county's right of way was a mere easement, the prior easement rights of the plaintiff were subordinate to the pubhic use of the land for highway purposes. Moreover, the court found that with changing traffic conditions a city or county may adapt its highways for the public good, the public use having priority over all other uses regardless of time of acquisition. ${ }^{110}$

In a more recent case, Galeb v. Cupertino Sanitary District, ${ }^{120}$ the court was confronted with the question of the scope of public easements. Streets had been dedicated in accordance with the Map Act; sewers had been located beneath the streets prior to the dedication. In deciding whether the street easement included the sewers, the court ${ }^{\mathbf{1 2 1}}$ pointed out that a governing body, while holding a mere easement, acquires more than a right to use dedicated streets. The local government has a right

117106 Cal. App. 2d 787, 236 P.2d 199 (1951).

118 Citing City of Pasadena v. California-Michigan Land \& Water Co., 17 Cal. 2d 576, 110 P.2d 983 (1941), in which a city lield the prior water-line easement expressly granted by the owner. Since there was apparently no intent to grant an exclusive eascment to the city, the court held that owners of the servient tenement could make any use of the land not unreasonably interfering with the easement, including tire grant of a subsequent water-line easement to the defendant water company. Only when the subsequent easement interfered unreasonably with the city's prior easement would the city's easement prevail.

110 In contrast, priority in time is an essential consideration when private easements compete. See, e.g., Murphy Chair Co. v. American Radiator Co., 172 Mich. 14, 27-28, 137 N.W. 791, 796 (1912), in which the first easement was given prior rights because prior in time and because used for pedestrian and vehicle trafic.

120227 A.C.A. 315, 38 Cal. Rptr. 580 (1964).

121 Quoting City \& County of San Francisco v. Grote, 120 Cal. 59, 52 Pac. 127 (1898), in which it was held that a municipality niay maintain an ejectnent action to recover possession of a public street or highway. In discussing this case, one author has said: "It is somewhat difficult to see how a mere right of user in the public can confer on the municipality a right of possession, sufficient to sustain ejectment, it being conceded that a private individual having a nere right of user, that is, an easement, can have no such right of possession .... [I]t seems desirable, for the purpose of legal theory, to deny the element of possession to a mere right of using the land." 4 TrFfany, Reat Property $\S 1112$, at 367 (3d ed. 1939). It could be argued, however, that sustaining an action for ejectment is justified on public policy grounds. Such a right is necessary if the governing body is adequate to protect the public's right to unrestricted use of public ways. 
of exclusive possession and can thus maintain an action for ejectment. Moreover, the city or county has an interest in the streets consistent with the public enjoyment of the streets and may, therefore, grade and improve the surface and may install various utilities below the surface. The court held that the dedication of a street is not limited to the surface, but includes utilities located below the surface even though installed before the dedication.

As the cases indicate, a public easement is much broader in scope than rights incident to a private easement-a necessary and desirable result. Since sucli use can be made of the land as is necessary for the enjoyment of the public, the governing body may adequately maintain the easement and may prevent private interference with the public use. That the governing body holds a mere easement becomes relevant only if the lands are misused or abandoned: If the lands are misused, the person who loolds the underlying fee may enjoin the misuse; ${ }^{122}$ if the lands are abandoned, the easement merges into the underlying fee. ${ }^{123}$

\section{H. Problems of Rejection and Revocation}

While under the doctrine of common law dedication an offer of land to the public can be revoked at any time before it is accepted, ${ }^{124}$ when land is offered for dedication under the provisions of the Subdivision

122 See, e.g., Gurnsey v. Northern Cal. Power Co., 160 Cal. 699, 117 Pac. 906 (1911).

${ }^{123}$ See, e.g., CaI. Stris. \& HignS Code $\$ 960$. This section provides that upon order of abandonment, the public easement reverts to the respective owners except to the extent reserved to the governing body in the order. The same result has been achieved in other jurisdictions by a finding that the governing body loolds a fee interest in trust for the public which reverts to the abutting owner or the original dedicator upon abandonment. See, e.g., Olin v. Denver \& R.G.R.R., 25 Colo. 177, 53 Pac. 454 (1898), which points out that there is a division of authority as to whether the title reverts to the original dedicator or to the abutting owner upon abandonment of the fee interest in a street. In California once the adjoining land is sold, it is presumed that the dedicator retains no legal interest in the streets. Brown v. Bachelder, 214 Cal. 753, 7 P.2d 1027 (1932). See generally Prall v. Burckhartt, 299 Ill. 19, 132 N.E. 280 (1921); Annot., 18 A.L.R. 1008-23 (1922).

Also, it sloould be noted that under Streets \& Higlwways Code $\S 903$ a county may acquire title to land opened for highway use in accordance with the terms of the order opening the higliway. The statute implies that a county may acquire a fee interest in a highway if it so declares in the order opening the highway.

124 County of Inyo v. Given, 183 Cal. 415, 191 Pac. 688 (1920) (filing of petition for abandonment and placing fence across property); City of Eureka v. Croghan, $81 \mathrm{Cal}$. 524, 22 Pac. 693 (1899) (conveyance of land without mention of offer of dedication). If the offer is not revoked, the public or the governing body may accept the lands unless an unreasonable amount of time has passed since the offer. Compare Yuba City v. Consolidated Mausoleum Syndicate, 207 Cal. 587, 279 Pac. 427 (1929) (31 years not unreasonable), with People v. Reed, 81 Cal. 70, 22 Pac. 474 (1889) (over 20 years unreasonable). An acceptance may occur even thougl the governing body initially refused the offer of dedication. See Tischauser v. City of Newport Beach, 225 A.C.A. 181, 37 Cal. Rptr. 141 (1964). 
Map Act ${ }^{125}$ and any street, path, alley, or storm drainage easement ${ }^{126}$ is rejected, the offer remains open and the city or county may at a later date rescind its rejection and accept the lands for public use. This right to accept can be terminated by statutory abandonment, by approval of a resubdivision, or by reversion to acreage. ${ }^{127}$ If, however, after recordation of the final map no lots are sold within five years or no required improvelnents are made within two years, the governing body may by resolution revoke its approval of the map and "all streets, ways and other easements dedicated or offered for dedication by such map shall be of no further force or effect."

While providing the governing body with a means of accepting the designated lands when they are offered, this statutory departure from cominon law principles can prove a pitfall to the unwary subdivider or lot owner. In Stump v. Cornell Construction Co., ${ }^{120}$ for example, a proposed subdivision was approved by the city subject to the condition that the subdivider offer a future alley for dedication. When the final map was approved, the city, apparently planning the alley for future use but not desiring prematurely to assume maintenance expense, accepted all dedicated lands except the future alley and a future street. Subsequently, the plaintiff purchased a lot adjacent to the proposed alley, the deed including no reference to the dedication of the alley. Several years later the city council adopted a resolution accepting the strip as a public alley and the plaintiff brought an action to quiet title on the theory that the conveyance from the subdivider to the plaintiff amounted to an implied revocation of the offer. While admitting that under common law doctrines a conveyance without reservation revokes an offer of dedication, the court held that the Subdivision Map Act was designed to prevent such an implied revocation. The court reserved its opinion as to whether the Act permitted an express revocation.

125 Cal. Bus \& Prof. Code § 11616.

126 Apparently common law principles still apply to the rejection and revocation of offers of recreational and school lands made under the Subdivision Map Act.

${ }^{127}$ The procedure for abandonment is prescribed by Streets \& Highways Code $\S \S 940-85,8300-74$. The procedure for reversion to acreage is prescribed by Business \& Professors Code $\$ 1153 \%$.

128 Cad. Bus. \& Pror. Code $\S 11640$. The statute does not apply to park or other recreational lands which, upon dedication, are held in fee simple by the governing body. Morse v. E. A. Robey \& Co., 214 Cal. App. 2d 464, 29 Cal. Rptr. 734 (1963). The wary subdivider, therefore, will expressly revoke his dedication offer of open spaces. If these lands have been accepted and dedication is complete, they will continue to be held by the governing body despite revocation of approval of the final map under $\S 11640$. The subdivider may be able to recover the lands or repurchase the lands under an abandonment procedure. See, e.g., CaL. Gov'T CodE \& 25561.

12929 Cal. 2d 448, 175 P.2d 510 (1946). 
The question of express revocation was answered in County of Orange v. Cole. ${ }^{130}$ Seven years after the rejection of a street offered for dedication under the Map Act, the abutting owners sent a notice to the local board of supervisors revoking the offer. A few months later, the city accepted the offer of dedication and initiated a quiet title action to secure an easement for the public. The appellate court rejected defendant's argument that the city could rescind its rejection and accept the offer only if the offer remained open, holding that revocation can be achieved only by the nrethods prescribed by the Map Act. ${ }^{131}$

Surely when sparsely settled suburban areas are improved, the local government should not be required to assume immediately the expense and habilities appurtenant to dedicated streets merely because the public officials by competent planning can foresee only a future need for such easements. ${ }^{132}$ Rather, the governing body should be able to delay its acceptance of the parcel until it is clearly worth the expense to the taxpayer. The Subdivision Map Act allows this desirable procedure, but the Act has no provision for insuring that an indication of the right to future acceptance will be included in an abutting owner's deed. As the cases suggest, subdivision lot owners are often unaware that their property is subject to a future pubhic easement, and being uncertain of their rights, they may improve the land. A possible solution is to require by statute that the subdivider mclude a description of all lands offered for dedication in the deeds of any affected lot owners. Also, the local government should be required to inform the subdivider and the landowners of the right to later acceptance of initially rejected lands so that statutory methods of revocation can be utilized. When the local governnent exercises its right of acceptance, a lot owner who was not informed of the local government's right to future acceptance should be allowed to recover from the party responsible for his ignorance the loss in value of his property plus the cost of removing any improvements made on the public land.

It should be noted that private landowners now possess a means of terminating the governing body's right to accept other than by resubdi-

13096 Cal. App. 2d 163, 215 P.2d 41 (1950), hearing denied.

131 More recently, a governing body was allowed to rescind its rejection and accept an offer of dedication fifteen years after the initial rejection. Quacchia v. County of Santa Cruz, 164 Cal. App. 2d 770, 331 P.2d 216 (1958); accord, Galeb v. Cupertino Sanitary Dist., 227 A.C.A. 315, 38 Cal. Rptr. 580 (1964) (12 years).

182 Even with lands dedicated under common law principles, the courts have not hesitated to find dedication of streets initally rejected but improved at a later date by the governing body. See, e.g., Tischauser v. City of Newport Beach, 225 A.C.A. 181, 37 Cal. Rptr. 141 (1964). 
vision, reversion to acreage, or formal abandonment as prescribed by the Map Act. Section 748.5 of the California Code of Civil Procedure provides:

Whenever a proposal ${ }^{133}$ to dedicate land for any public improvement has been heretofore or hereafter made by map only, without any acceptance of the dedication being endorsed thereon, and the land has not been used for the purpose for which the dedication was proposed for a period of 25 years, and the property has been subsequently sold to a third person, after the filing of the map, and used as if free of the dedication, there is a conclusive presumption that the proposed dedication was not accepted, and a suit to quiet title to such land naming the governmental agency to which the dedication was made by map as defendant, the decree in favor of the plaintiff shall clear title of the proposed dedication and remove the cloud created by the proposed dedication.

As yet no cases have passed upon the problems of interpretation created by the statute. Suppose, for example, that lands offered for dedication by map are accepted twenty-six years after the date of the offer. Assuming that all the requirements of the statute were satisfied for a twenty-five year period after the offer can a private party claiming ownership in the land quiet title in accordance with the words of the statute which assert that there is a conclusive presumption that the dedication was not accepted? It seems clear from the terms of the Map Act as interpreted by Stump and Cole that the offer may be accepted any time before the landowner has resubdivided the land or reverted the land to acreage, or before he has quieted title under section 748.5, even though the owner has made improvements on the land. ${ }^{134}$ If improvements were made by the governing body after the land had been unused for twentyfive years, the rehance by the governing body would introduce an element of estoppel. Section 748.5 should only apply if a quiet title action is brought before actual acceptance or use by the governing body even though the acceptance or use takes place more than twenty-five years after the proposal of dedication.

An additional problem presented by section 748.5 is whether the twenty-five year period may begin running before 1955, the date of enactment. One case ${ }^{135}$ held that the statute could not apply retroactively to affect a vested property right, but the lands in question had been accepted and dedication was complete long before 1955. If, how-

133 The word "proposal" has been defined as an offer in Corey v. City of San Diego, 163 Cal. App. 2d 65, 71, 329 P.2d 99, 103 (1958).

134 One Cahifornia case, City of Imperial Beach v. Algert, $200 \mathrm{Cal}$. App. 2d 48, $19 \mathrm{Cal}$ Rptr. 144 (1962), has allowed a private owner to reclaim lands offered and accepted for dedication on the theory of equitable estoppel. See note 21 supra.

135 McKinney v. Ruderman, 203 Cal. App. 2d 109, 21 Cal. Rptr. 263 (1962). 
ever, a quiet title action were brought before acceptance and after twenty-five years, but only ten years after 1955 , there would be no acceptance, apparently no vested property right would be adversely affected, and the legislative declaration that the statute apply "heretofore or hereafter" probably would control.

\section{CONCLUSION}

From the need for land-use planning, a well-defined procedure for dedication has arisen. There is imposed on every subdivision land developer a uniform system for improvement and donation of subdivision streets and other easements. With few exceptions, both the donor and the donee are certain of the legal status of dedicated lands. Uncertain areas of the law such as the revocation provisions of the Map Act can be refined by further legislation. Moreover, the courts have been aided in their interpretation of the Map Act by a legislative policy and an integrated body of statutes. When the courts have erred, the legislature has been able to remedy the error without creating further confusion. In the future, as public policy changes, the legislature can amend or supplement the Act; for example, provisions may be enacted for compulsory dedication of park or other recreational lands.

In contrast, there are numerous procedures for donation of land to the public under common law doctrimes of dedication. These modes of dedication are usually informal, often making it unclear whether private lands lave in fact been donated to the public. For example, it is a question of fact which can only be determined by a jury whether lands have become public by adverse user-both the offer and the acceptance are implied from the conduct of the donor and the donee. Hasty, ad hoc legislative interference with common law doctrines of dedication has created further uncertainty. Since the enactment of the Subdivision Map Act, private lands are less frequently donated to the public under common law doctrines of dedication, but in rural areas where land development by subdivision is seldom used, common law dedication is of continumg importance. Moreover, private benefactors often donate lands to a governing body under common law doctrines of dedication. The legislature should, therefore, codify these common law doctrines in a cautious, orderly, and uniform manner. 